\title{
Suicide and suicide attempts by the elderly in film: related factors as shown in feature films
}

Laércio Maciel Scalco ${ }^{1}$

Juvenal Fernandes dos Santos Monique Gomes da Silva Scalco ${ }^{2}$ Armando José China Bezerra' Vicente de Paula Faleiros ${ }^{1,3}$ Lucy Gomes ${ }^{1,3}$

\section{Abstract}

Objective: to analyze cases of suicide and suicide attempts by elderly persons in feature films. Method: a survey of specialized internet cinema portals was carried out. A total of 19 feature films produced between 1950 and 2014 were identified. After the authors watched the films, synopses were written describing the circumstances of the suicide and dialogue that described the profile of the elderly character was transcribed. Results: films that described suicide among the elderly were classified as follows: male gender in 13 films (68\%), depression with hopelessness in 12 (63\%), existence and efficiency of health services, physical illness and absence of familiar support in ten (for each category) $(53 \%)$, cognitive rigidity in eight (42\%), suicidal thinking in seven $(37 \%)$, dysfunctional assumptions and a self-perception of negativity in six $(32 \%)$, problem-solving deficits in five $(26 \%)$ and a lack of social support in five $(26 \%)$. Conclusion: the portrayal of suicide among the elderly in films helps to raise awareness of this subject and prevent it.

\footnotetext{
Universidade Católica de Brasília, Escola de Medicina. Brasília, DF, Brasil.

2 Universidade de Brasília, Faculdade de Medicina, Programa de Pós-Graduação em Ciências Médicas. Brasília, DF, Brasil.

Universidade Católica de Brasília, Programa de Pós-Graduação Stricto Sensu em Gerontologia. Brasília, DF, Brasil.
}

Keywords: Suicide. Suicide Attempt. Elderly. Films. 


\section{INTRODUCTION}

Suicide is a global public health problem that is currently responsible for more than one million deaths worldwide, and is an especially serious issue among the elderly ${ }^{1}$. According to the World Health Organization, the number of suicides increases steadily over the life span of both men and women, reaching its highest rates among those with a more advanced age ${ }^{2}$.

One of the ways of understanding the phenomenon of suicide among the elderly is through its representation in cinematographic art. Cinema optimizes the possibility of seeing, hearing and experiencing something experienced in reality in a protected manner ${ }^{3}$. However, the number of films showing elderly suicidal characters does not correspond to reality ${ }^{4}$. A survey carried out of cinematographic works from 1900 to 2014 showed that most films portray the experience of young people, as this is the preference of the consuming public ${ }^{4}$.

The objective of the present study was to analyze the various representations of suicides and suicide attempts among the elderly population in feature films, highlighting the characteristics that could be considered related factors.

\section{METHOD}

Brazilian and international titles were surveyed, with all films produced between 1950 and 2014 that portrayed elderly persons with suicidal ideation or that had committed suicide included. The following portals specializing in cinema were accessed in February and March 2015 : www.imdb.com (Internet Movie Data Base), www.nfb.ca (National Film Board of Canada), www.cinema10.com.br, www.adorocinema. com, www.cinemateca.gov.br, www.filmesdecinema. com.br, www.cineplayers.com, www.interfilmes.com, www.cineclick.com.br and www.revistaforum.com. br. The terms "suicide and the elderly" and "suicide and aging" were used, along with their respective equivalents in English and Spanish.
The selected films were watched separately by each of the authors of the study. After screening, synopses were written describing the construction of the suicides of the elderly characters. Whenever possible, quotes from the characters with a suicidal profile were transcribed. The characters were classified according to the following related factors: depression with hopelessness, a negative self-concept, cognitive rigidity and dysfunctional presuppositions, problem solving deficit, physical illness, lack of family and social support, existence and efficiency of health services, and gender.

\section{RESULTS AND DISCUSSION}

Table 1 shows the 19 films analyzed in chronological order of production in the period from 1950 to 2014.

There follows a synopsis of each of the films, focusing on the factors related to the suicidal conduct of the elderly persons.

\section{Sunset Boulevard}

The film describes the relationship between Joe and Norma, an aging silent movie star who dreams of returning to the cinema screens. Joe realizes that Norma lives in a fantasy world, sustained by her butler, and uses this relationship for financial gain. Egocentric, histrionic and disconnected from reality, Norma suffers from frequent depressive episodes during which she tries to kill herself.

\section{Humberto D}

Set in Italy in the 1950s, where retired people protest in the streets seeking an increase in their pensions. Umberto Domenico is one such pensioner, and sells his few possessions to get the rent for the room where he sleeps. To avoid eviction, he tries unsuccessfully to borrow from his friends and begs in the street, eventually abandoning the lodging house with his dog. The character then attempts suicide. 
Table 1. List of 19 films produced between 1950 and 2014 which dealt with the subject of suicide among elderly individuals. Brasília, Federal District, 2014.

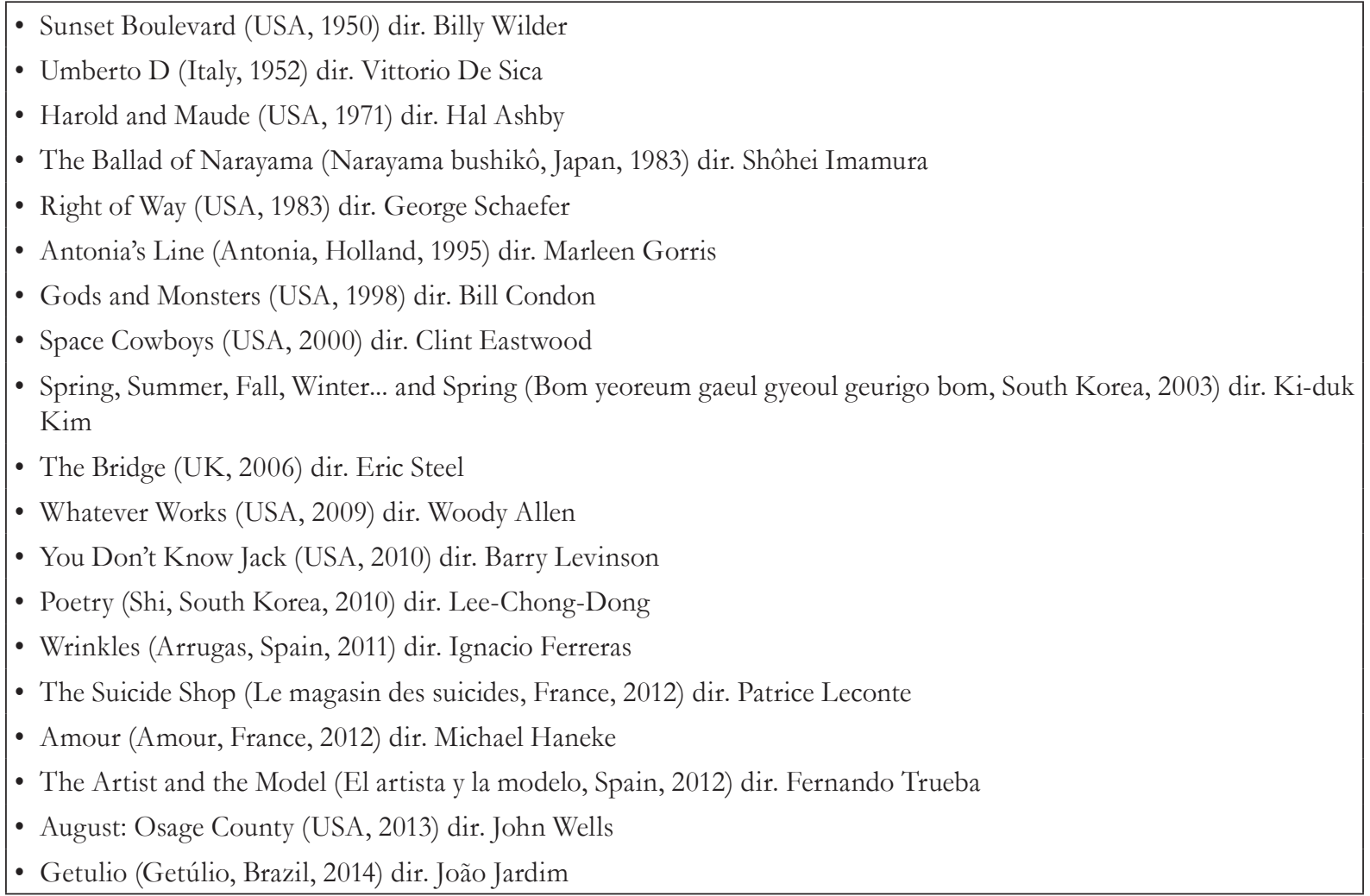

\section{Harold and Maude}

The film tells the story of the loving relationship between Harold, a depressed 20-year-old, and Maude, a 79-year-old woman who teaches him to love life. They both fall in love and decide to get married. To Harold's surprise, however, Maude had already made the decision to commit suicide when she turned 80, considering herself "an old woman" and carries out her plan.

\section{The Ballad of Narayama}

The film portrays a rural region of 19 th century Japan, where there is a tradition of taking elderly people, at the age of 70 , to the summit of Narayama Mountain where they are left to die. According to the tradition, at the end of their lives, everyone arrives metaphorically on the summit of this mountain and finds their deaths there. The elderly characters accept death as the end of a cycle, not wishing to live an old age with physical limitations and dependence. They also sacrifice themselves to help with the distribution of food, which is insufficient for everyone.

\section{Right of Way}

The story of an elderly couple who are happy until the woman is diagnosed with a terminal illness. Even though the husband is healthy, the couple decide to commit joint suicide, apparently fully aware of their situation. They explain the decision to their only daughter: "We've lived our whole life together and have decided that we want to die together." 'They are approached by a representative of the town who decides to provide them with legal representation. "We just want to be together. Why is that so hard to understand?" says the elderly character. The couple commit suicide.

\section{Antonia's Line}

The film tells the story with death as a central theme, as well as the suicide of the character Crooked Finger, a lonely elderly person, who says: "We ourselves invented time...old people stink of the time that has passed." Crooked Finger's speech is loaded with negativity. At one moment, he says: "Disgrace is the rule. Not the exception. I have never been able 
to accept the simple concept that everything will improve one day. Nothing will improve. Nothing will be better, or worse, it will only be different." Finally, Crooked Finger hangs himself.

\section{Gods and Monsters}

The film tells the story of James Whale, director and creator of the film Frankenstein, when he is old and retired. It describes his stroke and subsequent suffering from a serious neurological condition. James had a poor upbringing and, as an adult, was never able to accept his past. Now, when he is old, his memories trouble him: "I've spent most of my life outrunning the past. Now it's flooding all over me." These memories sadden him, and he decides to commit suicide.

\section{Space Cowboys}

Agents are called in to fix a malfunctioning satellite, which can only be repaired by sending a team of elderly workers to carry out the work in space. "Well ... this old man's all you got...I can't fill a space shuttle with geriatrics!" They discover that one of the pilots has incurable cancer. At one point in the mission, someone needs to guide the satellite with his own body, and so will inevitably be lost in space. The sick pilot accepts the mission, in an altruistic suicide.

\section{Spring, Summer, Fall, Winter... and Spring}

A portrayal of two unnamed Buddhist monks. The elderly monk, who lives by a lake in the wilderness, receives a child, to whom he teaches respect and discipline. However, when the young monk becomes an adult, he moves to the city where he commits a serious crime and is arrested. The monk now lives alone and, with the passage of time, decides to commit suicide through self-immolation. The suicide of the elderly character appears to be socially and religiously accepted, representing the resumption of a cycle, the beginning of a new life through transformation into an animal (snake). The young monk returns home and lives alone until he takes in a child to raise, just as his predecessor did before him.

\section{The Bridge}

A documentary about suicides on the Golden Gate Bridge, San Francisco, USA in 2004. In the opening minutes, a man, who appears to be around 70 , stares at the horizon, then jumps into the sea 67 meters below. The coastguard retrieves the body. The documentary is produced through a camera that for one year recorded events from the side of the bridge. Although there are numerous testimonials from relatives, there are no interviews with relatives of the elderly character described

\section{Whatever Works}

Boris is a grumpy elderly character who suffers from panic attacks. He is confident in his intellectual capacity and makes frequent pessimistic reflections on humanity. "A bigger part of your existence is luck than you'd like to admit," he says. Near the end, he is disappointed in love with a woman who had loved him as a young man. Boris seems to accept the situation, but hours later, he jumps out the window in a failed suicide attempt. " Everybody's life is still worth saving? (...) They've had to install automatic toilets in public restrooms, because people can't be entrusted to flush a toilet."

\section{You Don't Know Jack}

Documentary on the assisted suicide and bibliography of Dr. Jack Kevorkian. Among the patients described is a debilitated elderly person with chronic obstructive pulmonary disease. The patient abandons his self-extermination attempt and then requests to start again. Although several actual cases of suicide are shown in the film, the characteristics of the patients are poorly explored.

\section{Wrinkles}

An animation about the elderly Emilio, who lives in a long-term care facility for the elderly (LTCFE). He has difficulty adapting to his new environment, where 
he has nothing to do and rarely receives visits from family members. Although his suicide attempt does not succeed, in one of the scenes a depressed Emilio walks fully dressed and alone into the swimming pool of the gymnasium.

\section{The Suicide Shop}

The film tells the story of a family that sells things to help people commit suicide. An old woman wants to buy a gun which does not make noise or create a mess, while another old woman wants to buy rope to kill herself. A suicide bomber goes to the store accompanied by an elderly character who explains that he is not suicidal, rejecting the expectation that he is the natural candidate to perform such an act. Other notable lines of the characters include: "What's the point of resisting when life isn't rosy, and when our state of mind is sad? What's the use of fighting against pessimism?"

\section{Amour}

Tells the story of the octogenarian couple Georges and Anne. She suffers from a stroke and refuses to be cared for outside her home. The task falls upon her husband, who initially hires a formal caregiver who psychologically abuses the patient. Anne progressively develops vascular dementia. They have a small social network, living partially isolated from society, eventually interacting with their daughter. Georges performs euthanasia on Anne and the story suggests that he then commits suicide.

\section{The Artist and the Model}

Marc is an elderly artist who lives in the French countryside, creating drawings, paintings and sculptures. One day, his wife gives shelter to a young refugee, who becomes a model for Marc. The artist begins to feel sexual attraction for the model, a desire which is frustrated when he confesses this fact to his wife. He had no expectations for the future, and so he has made no plans. "Where do you want me to go? I'll die soon enough," he says, adding "When we start to figure things out it's because it's time to go." He says goodbye to the model before committing suicide.
Poetry

The film tells the story of Agnes, a 65-year-old woman diagnosed with Alzheimer's disease, whose life revolves around taking care of her grandson. She is informed that he has participated in the gang rape of a 16-year-old girl, and turns him over to the police. She works as a formal caregiver for a braindamaged man who tries to seduce her. She participates in a poetry club, but cannot write, stating, "To write a poem, you must have a heart," Progressively, she becomes depressed, cutting herself off and clinging to the memories of the dead girl, unable to find a meaning to live. The film ends with her disappearance, suggestive of suicide: "Now it's time to say goodbye, like the wind that remains and then goes. Exactly like the shadows."

\section{August: Osage County}

The film tells the story of an elderly couple. He is an alcoholic and she is undergoing treatment for cancer. They live in the countryside, isolated and removed from their children, until one day he decides to leave his wife and commit suicide. The characteristics of this elderly suicidal character are not explored in depth. However, the family environment in which he is inserted leads one to believe that the act was motivated by the few family ties that surrounded him.

\section{Getúlio}

The story of the former Brazilian president who died at the age of 72 after living with pressure from the political enemies and journalists who persecuted him with a series of personal attacks. As a result, opinion turned against him, and he was the subject of hostile demonstrations whenever he appeared in public. His daughter found a draft of a farewell letter and suspected he had suicidal intentions. When she confronted him, however, Getúlio denied this was his intention. He planned his death, recording a posthumous message which read: "I follow my destiny. There is nothing more I can give you except my blood. I was a slave to the Brazilian people, and today I am freeing myself for eternal life. I leave life to enter history." 


\section{Cognitive factors and psychiatric disorders}

Suicidal individuals often suffer from mental illnesses, whether depressive and/or personality disorders or conditions involving alcohol or other drug abuse ${ }^{5}$.

Risk factors for suicide among the elderly involve suffering that crosses social, cultural, psychological, environmental and biological dimensions. Such factors combine with the unique experience of the deceased $^{6}$. It is the negative interpretation of risk factors makes the individual more vulnerable, rather than the simple existence of the same.

The 19 films analyzed highlighted factors related to the suicide of the elderly. They showed: dysfunctional assumptions ( $\mathrm{n}=6 ; 32 \%)$; Cognitive impairment ( $\mathrm{n}=8,42 \%)$, problem solving deficit $(n=5,26 \%)$, negative self-concept $(n=6,32 \%)$, previous suicidal ideation $(\mathrm{n}=7 ; 37 \%)$, depression with hopelessness $(n=12 ; 63 \%)$, the male gender $(n=13$; $68 \%$ ), existence and efficiency of health services $(\mathrm{n}=10 ; 53 \%)$, physical illness $(\mathrm{n}=10 ; 53 \%)$ and lack of family $(n=10 ; 53 \%)$ and social support $(n=5 ; 26 \%)$.

Focusing on the reasons that lead the elderly to suicidal behavior allows the visualization of the relevance of the existential dynamics and the sufferings that they consider to be unbearable. Thus, the analyzed films visualize scenarios in which these factors combine and overlap with each other. Each of these characteristics is discussed below.

\section{Depression and hopelessness}

Depression in the elderly is often associated with suicidal behavior, ${ }^{6}$ as those in a depressive state lose their ability to cope with stressors, compared to those who do not present such symptoms? ${ }^{7}$. It is the most important element in a significant portion of suicide attempts, arising from the emptiness, discomfort and sense of worthlessness it produces ${ }^{8}$.

Hopelessness is a key psychological variable in suicide, being a related factor as well as a predictor?. It is an omnipresent theme in Umberto D, in which Umberto does not imagine that his life can improve. In the film Poetry, Agnes sees no reason to live after the arrest of her grandson, just as Georges, in Amour, sees no meaning in life without the company of the wife.

The alcoholic husband of August: Osage County has no hope living in a damaged family environment. Getúlio does not see any possibilities in his presidential career. Maude, from Harold and Maude, glimpses a gloomy future after turning 80 and does not believe that life can be enjoyed in old age. In The Artist and the Model, the elderly character is hopeless, though not unhappy, which also occurs in some of Dr. Jack's patients in You Don't Know Jack. In the latter, all the patients lack a reason to live and do not believe that it is possible to overcome their diseases.

In The Suicide Shop, Carmel and other characters synthesize hopelessness, as for them the present and future worlds do not offer hope, and they see suicide as the only alternative for relieving suffering. In Whatever Works, Boris apparently believes that with the end of his relationship, it is no longer possible to be happy, seemingly also believing that resuming the courtship is impossible. In Right of Way, when the woman receives the diagnosis of terminal illness, the couple opts for suicide in the hope of remaining together in the afterlife.

In Wrinkles, Emilio thinks that he will never leave the LTCFE due to his chronic condition. Some chronic diseases are presented in literature as a risk factor for suicide?. The same occurs with James Whale in Gods and Monsters, who suffers depression after a stroke, the physical disease that is most often associated with this condition ${ }^{10}$. In the film Antonia's Line, Therese reads a letter written by Crooked Finger in which his hopelessness is evident. Finally, the association between hopelessness and suicidal desires in psychiatric outpatients is illustrated by Norma Desmond in Sunset Boulevard, and by Boris in Whatever Works, who had previously attempted suicide.

\section{Negative self-concept}

The exaggerated importance given to the constant multiplication of economic sources causes the elderly to be seen as an unproductive 
population group. In addition, the concern with aesthetics and permanent youth leads them to feel ashamed of themselves, presenting negative selfconcept $\mathrm{t}^{5}$. This is an indicator of suicide risk in adults, independent of hopelessness, although literature does not specifically indicate this risk in the elderly?

The negative cinematic accounts of old age, as expressed by Maude in Harold and Maude and Crooked Finger in Antonia's Line, probably denote a negative self-concept. In these cases, they demonstrate shame at being old and sick. Getúlio, in the film of the same name, also suggests negative self-concept, as the rejection that he suffers from the crowds affects him more than simple popular rejection. In Gods and Monsters, Whale blames himself for developing and nurturing a loving feeling for another man. What afflicts him most is that he believes himself to be unfaithful to his deceased former boyfriend, with whom he had been in love. Perceiving oneself as a burden on others or being considered worthless also reflects negative selfconcept ${ }^{6}$ being emblematic, in this sense, of the elderly characters in The Ballad of Narayama and Harold and Maude.

\section{Cognitive rigidity and dysfunctional presuppositions}

In depression, thinking becomes more rigid and distorted, judgments become absolute, and the individual's basic beliefs about the self, the real world, and the future become negatively restricted. Logical errors negatively distort perceptions and inferences, contributing and leading to false conclusions ${ }^{11}$. In The Artist and the Model, the elderly character suffers from cognitive rigidity, as he is unable to evaluate something as average, but only as very good or terrible, with this rigidity being a factor related to suicide ${ }^{11}$. Boris, in Whatever Works, is also rigid, reacting catastrophically at the end of the courtship.

As depression is controlled, in most cases, so cognitive flexibility is regained and negative thoughts are diminished. For others, however, negative assumptions persist and favor the increasing severity of depression and, in some cases, the possibility of suicide. This seems to have been Norma Desmond's experience in Sunset Boulevard. Apparently suffering from a personality disorder, in situations in which she was distressed due to the loss of affective objects, she sees no alternative to the discomfort she experienced, other than suicide, which she achieves by cutting her wrists. There is a similar situation in Right of Way, in which the old woman does not show sadness, and may be exhibiting a profile of depression. Georges, the elderly husband in Amour, in turn, could be hiding symptoms of depression or, also, be selfless in his suicide so that his wife can have him by her side.

Dysfunctional presuppositions predispose suicidal ideation, ${ }^{12}$ as illustrated in The Ballad of Narayama, in which the characters believe that the final journey in life should be made by road to where God will be found at the end, i.e. at the summit of Narayama Mountain.

\section{Problem Solving Deficit}

There is a relationship between poor problemsolving skills and suicide ${ }^{11}$. In Brazil, a study with 20 elderly people who attempted suicide and began to overcome the impulse to take their own lives, identified coping strategies based on five nuclei: religiosity and religious practices; social and family support; support of health services; contact with pets (as observed in Umberto D) and resumption of the autonomy to manage one's life ${ }^{13}$.

Among the strategies for coping with crisis situations, there is a positive association with the religious dimension ${ }^{14}$. Religiosity exercises a function of protection, and comfort and offers answers to the adversities of life, as well as creating possibilities of interaction with others, when shared at community events. Support from religion, or a relationship with God, regardless of association with religious practices, is mentioned as fundamental to overcoming suicidal thoughts ${ }^{13}$. Religious institutions are also environments where new relationships and the learning of new activities arise, encouraging occupancy of time and the departure from places that represent suffering and, thus, enabling the reassuming of the capacity to make decisions, allowing focus to be shifted from the zone of discomfort and discontent represented by their problems, to new life projects ${ }^{15}$.

Suicides have difficulties in producing new ideas, identifying solutions and generating alternatives, and are less likely to engage when required ${ }^{11}$. The 
elderly artist character in The Artist and the Model has difficulty establishing relationships with his neighbors. When children approach, he frightens them with his carbine so they run away and do not come back. In Amour, when Georges kills his wife, he opts for a solution that allowed him to evade contact with her suffering. In Whatever Works, Boris is used to reacting explosively when put in an unpleasant situation. He does not attempt to persuade his exgirlfriend to resume dating and then attempts suicide.

\section{Physical illness}

APhysical illness is a risk factor for suicide among the elderly ${ }^{6}$. Functional deterioration and type of disease (mainly cardiac and joint disease) are independent predictors for depression among this group ${ }^{16}$. What most affects them is the loss of autonomy and intimacy which, together with the desire for a greater number of daily activities, emerges as an insistent demand of elderly people at risk of suicide $^{5}$. Association with the abusive use of alcohol and other drugs increases the risk of suicide ${ }^{8}$.

The cure or treatment of diseases, so improving quality of life is important for the elderly to regain the desire to live and overcome suicidal ideation. Improved health helps them to think about new life plans, which is fundamental for maintaining good self-esteem ${ }^{13}$.

This theme appeared in several the films analyzed, such as Right of Way, Space Cowboys, Gods and Monsters, You Don't Know Jack, Wrinkles, The Suicide Shop, Amour, Poetry and August: Osage County. As the majority of diseases are degenerative, they can also be accompanied by hopelessness.

\section{Family and social support}

Family support is embodied in the protection offered to the elderly by family members who demonstrate understanding, empathy and stimulate positive experiences ${ }^{17}$. By social support, we mean attitudes and actions of emotional, instrumental and material support, offered by institutions and professionals from the social and health areas, or by people in the community, to keep the elderly person independent and active. However, the quality of such relationships seems to be more important than the quantity ${ }^{17}$. Literature establishes a connection between the family and social context and suicide, as well as the impact of the same on families and the social circle ${ }^{18-20}$.

Globally, suicide is a more serious issue in lowand middle-income countries, with $75 \%$ such deaths occurring in these areas ${ }^{21}$. In older people, the restrictions imposed by their financial situations are even more severe, as they usually overlap with other types of problems, such as deprivation of living space, abandonment, either conscious or due to a lack of conditions to care for them on the part of relatives, dependency, difficulties due to illness or problems of age and the loss of their property, ${ }^{22}$ as in the case of the character of Umberto D.

The prevention of suicide among the elderly is linked to the enrichment of social networks, increased support and intervention against family dysfunction, and help to deal with the challenges of life in old age $^{2}$. Social disconnection has potentially negative effects on the mental health of the elderly, fueling a desire to detach themselves from society and to consider suicide ${ }^{23}$.

\section{Lack of family support}

The independence of elderly persons to make decisions about daily living, their assets and life itself is often restricted by the decisions of family members. This coercion is part of the circumstances that can be, for some, a trigger for the desire to $\operatorname{die}^{24}$.

The impact of intergenerational violence is often associated with suicidal ideation and acts ${ }^{8}$. Interviews with 63 elderly persons in 14 locations in Brazil showed that, in order of relevance, the influences of family problems and conflicts on suicidal ideations and attempts were: significant family losses, family and intergenerational conflicts, and explicit and concealed violence ${ }^{22}$.

A family history of suicides is strongly associated with the risk of self-inflicted deaths among the elderly ${ }^{1}$. The suicide of a relative brings, especially 
for the elderly, feelings ranging from sadness to desperation at not being able to do something about the death ${ }^{20}$.

In August: Osage County, the weak links between the suicide victim and the family and repetitive conflict appear linked to the suicide, just as the family violence is linked to the alcoholism of the couple. In the film Wrinkles, institutionalization, solitude and isolation are evident, with a scarcity of visits and a lack of attention from relatives. Residency in a LTCFE can lead to distancing from relatives, at a time in life when frailty is greater, and family visits decrease as the time of institutionalization increases. In these cases, affective ties are undone, increasing isolation, abandonment, emptiness and loss of the meaning of life $\mathrm{e}^{8,25,26}$.

Cohabitation with pets is considered a relevant alternative interaction, especially when the elderly person lives with an animal as though it were a member of the family. The individual-animal relationship is perhaps more intense and profound in old age than in any other life cycle, ${ }^{27}$ and thus the affective attachment of the elderly person with suicidal behavior towards a pet facilitates the overcoming of death wishes ${ }^{13}$. Faced with family distancing and loneliness, attachment to pets, as in Umberto D, stands out as a resumption of functional capacity - caring, not only being careful, feeling useful and loved, as well as filling the time.

\section{Lack of social support}

A lack of social support is a risk factor for suicide ${ }^{5}$. Social support deals with subjects ranging from forms of welcoming old people to institutional care. Relationships of friendship are significant elements in situations of risk for suicide attempts, highlighting the importance of extra-family social ties in everyday life28. Although many older people feel excluded and misunderstood by family members, they may find among their friends the welcome they need to continue their lives and carry out their plans. Hence, cultivating these relationships is a protective factor against ideation, attempts, and effectuation of selfinflicted death1. The relationships of friendship and companionship were also highlighted by the elderly persons living in LTCFE, where they create new emotional bonds that give them emotional support, particularly in the absence of relatives.
In Poetry, the protagonist raises her grandson without help from anyone, while in the movie Amour, the elderly character takes care of his wife alone. In Umberto D, Umberto does not have enough money to support himself and has no one to turn to. In Wrinkles, the elderly character is institutionalized and develops new friendships in the home.

\section{Existence and efficiency of health services}

Studies have indicated a relationship between a precarious or non-existent mental health care network and a higher incidence of suicide among the elderly ${ }^{29}$. In another study, the elderly described how they are received in health services as important, particularly in Centros de Atenção Psicossocial (Psychosocial Care Centers) (CAPS), identified as appropriate spaces for the provision of integral care for people with psychic suffering and a death wish ${ }^{13}$.

The provision of care is not mentioned in The Ballad of Narayama, Umberto D, The Artist and the Model and Spring, Summer, Fall, Winter... and Spring. In Poetry, when providing the diagnosis of Alzheimer's disease, the doctor neither expresses interest in the repercussion of the news, nor mentions the potential follow-up treatment by health professionals to the patient.

\section{Gender}

The question of gender is the most significant distinguishing factor among suicide cases in terms of severity, the methods used, and the associated factors ${ }^{8}$.

A Brazilian study showed that most suicidal elderly women had suffered violence in each of their life cycles (childhood, youth, adulthood and old age), committing suicide after rigidly fulfilling the gender role imposed by the patriarchal society ${ }^{29}$. The following gender inequalities were found: beginning in childhood, with education differentiated by gender; continuing through youth, in sexual initiation, marriage and maternity; through adulthood, with violence perpetrated by an intimate partner and/or other family members; and culminating in old age when deprived of autonomy, with the loss of ties, assets and references ${ }^{29}$. 
Of the 19 films analyzed, seven patients were female, while 14 were male. Thus, cinema seems to mirror the prevalence of the male gender in cases of elderly suicidal characters.

\section{CONCLUSION}

Considering the vulnerability of the elderly population to death by suicide, it is important to gain a better understanding of suicide attempts and ideations, as well as thoughts and behaviors related to such attempts and ideation. The cinematographic treatment of the subject represents a useful contribution, providing comprehensive images of the antecedents of the suicide, thus indicating effective

\section{REFERENCES}

1. Conwell Y. Suicide in later life: challenges and priorities for prevention. Am J Prev Med. 2014;47(3 Suppl 2):244-50,

2. World Health Organization. The World Health Report 2001. Mental Health: New Understanding, New Hope. Geneve: WHO; 2002.

3. Dantas AA, Martins CH, Militão MSR. O cinema com instrumento didático para a abordagem de problemas bioéticos: uma reflexão sobre a eutanásia. Rev Bras Educ Méd. 2011;35(1):69-76.

4. Stack S, Bowman B. Suicide movies: social patterns 1900-2009. Cambridge: Hogrefe Publishing; 2011.

5. Fachola MCH, Lucero R, Porto V, Diaz E, Paris MA. Suicide attempts and suicide ideation among the elderly in Uruguay. Cienc Saúde Coletiva. 2015;20(6):1693-1702.

6. Cavalcante FG, Minayo MCS, Mangas RMN. Diferentes faces da depressão no suicídio em idosos. Ciênc Saúde Coletiva. 2013;18(10):2985-94.

7. Kraaij V, Pruymboom E, Garnefski N. Cognitive coping and depressive symptoms in the elderly: a longitudinal study. Aging Ment Health. 2002;6(3):275-81.

8. Cavalcante FG, Minayo MCS. Estudo qualitativo sobre tentativas e ideações suicidas com 60 pessoas idosas brasileiras. Ciênc Saúde Coletiva. 2015;20(6):1655-66.

9. Salkovskis P, Wolpert L. Does psychoanalysis have a valuable place modern mental health services? BMJ. 2012;344:1188. and efficient methods of detection and prevention of deaths that are avoidable.

In Brazil, there are no public policies aimed at the elderly that dialogue with the phenomenon of suicide, which hinders access to adequate health care for those with such a need. The lack of these policies intensifies the problems of the elderly, especially those who do not have a healthy family life and who have few options in coping with and solving conflicts. With the discussion of the theme through cinema, one obtains knowledge of the characteristics of suicide and suicide attempts, enabling the implementation of strategies of prevention, detection and intervention in primary health care aimed at elderly persons with ideas of suicide or a history of suicide attempts, to reduce the chance of them becoming suicidal.

10. Terroni LMN, Leite CC, Tinone G, Fraguas Jr R. Depressão pós AVC: fatores de risco e terapêutica antidepressiva. Rev Assoc Méd Bras. 2003;49(4):450-9.

11. Salkovskis PM. Fronteiras da terapia cognitiva. São Paulo: Casa do Psicólogo; 2004.

12. Bonner RL, Rich AR. A prospective investigation of suicidal ideation in college students: a test of a model. Suicide Live Threat Behav. 1988;18(3):245-58.

13. Figueiredo AEB, Silva RM, Vieira LJES, Mangas RMN, Sousa GS, Freitas JS, et al. É possível superar ideações e tentativas de suicídio? Um estudo sobre idosos. Ciênc Saúde Coletiva. 2015;20(6):1711-19.

14. Nock MK, Borges G, Bromet EJ, Cha CB, Kessler RC, Lee S. Suicide and Suicidal Behavior. Epidemiol Rev. 2008;30(1):133-54.

15. Figueiredo AD. Formar para as humanidades nas sociedades contextuais. Braga: Universidade Católica Portuguesa; 2006.

16. Yang YT, Wang YH, Chiu HT, Wu CR, Handa Y, Liao YL, Elsa YH. Functional limitations and somatic diseases are independent predictors for incident depressive disorders in seniors: findings from a nationwide longitudinal study. Arch Gerontol Geriatr. 2015;61(3):371-7.

17. Rios MA, Anjos KF, Meira SS, Nery AA, Casotti CA. Completude do sistema de informação sobre mortalidade por suicídio em idosos no estado da Bahia. J Bras Psiquiatr. 2013;62(2)131-8. 
18. Martinez VTP, Parra ZL. Repercusión familiar del comportamento suicida. Rev Cubana Med Gen Integr. 2004;20(5-6):1-6.

19. Krüger LL, Werlang BG. A dinâmica familiar no contexto da crise suicida. Psico USF. 2010;15(1):59-70.

20. Figueiredo AEB, Silva RM, Mangas RMN, Vieira LJS, Furtado HMJ, Gutierrez DMD, et al. Suicídio de idosos: impacto na família brasileira. Ciên Saúde Coletiva. 2012;17(8):1993-2002.

21. World Health Organization. Preventing suicide: a global imperative. Geneve: WHO; 2014.

22. Silva RM, Mangas RMN, Figueiredo AEB, Vieira LJES, Sousa GS, Cavalcanti AMTS, et al. Influências dos problemas e conflitos familiares nas ideações e tentativas de suicídio de pessoas idosas. Ciênc Saúde Coletiva. 2015;20(6):1703-10.

23. Durkheim F. O suicídio: um estudo sociológico. Rio de Janeiro: Zahar; 2011.
24. Meneghel SN, Gutierrez DMD, Silva RMS, Grubits S, Hesler LZ, Ceccon RF. Suicídio de idosos sob a perspectiva de gênero. Cienc Saúde Coletiva. 2012;17(8):1983-92.

25. Pinto LW, Assis SG, Pires TO. Mortalidade por suicídio em pessoas com 60 anos ou mais nos municípios brasileiros no período de 1996 a 2007. Ciênc Saúde Coletiva. 2012;17(8):1963-72.

26. Oliveira SC, Santos AA, Pavarini SCI. Relação entre sintomas depressivos e a funcionalidade familiar de idosos institucionalizados. Rev Esc Enferm USP. 2014;48(1):66-72.

27. Suthers-McCabe HM. Take one pet and call me in the morning. Generations. 2001;25(2):93-5.

28. Shah A, Bhat R. The relationship between elderly suicide rates and mental health funding, service provision and national policy: a cross-national study. Int Psychogeriatr. 2008;20(3):605-15.

29. Meneghel SN, Moura R, Hesler LZ, Gutierrez DMD. Tentativa de suicídio em mulheres idosas: uma perspectiva de gênero. Ciênc Saúde Coletiva. 2015;20(6): 721-30. 